University of South Florida

DIGITAL COMMONS

Digital Commons @ University of

@ UNIVERSITY OF SOUTH FLORIDA

South Florida

$5-2009$

\title{
Evaluation of Groundwater Storage Monitoring with the GRACE Satellite: Case Study High Plains Aquifer, Central United States
}

\author{
Gil Strassberg \\ University of Texas \\ Bridget Scanlon \\ University of Texas \\ D. Chambers \\ University of Texas, donc@usf.edu
}

Follow this and additional works at: https://digitalcommons.usf.edu/msc_facpub

Part of the Marine Biology Commons

\section{Scholar Commons Citation}

Strassberg, Gil; Scanlon, Bridget; and Chambers, D., "Evaluation of Groundwater Storage Monitoring with the GRACE Satellite: Case Study High Plains Aquifer, Central United States" (2009). Marine Science Faculty Publications. 192.

https://digitalcommons.usf.edu/msc_facpub/192

This Article is brought to you for free and open access by the College of Marine Science at Digital Commons @ University of South Florida. It has been accepted for inclusion in Marine Science Faculty Publications by an authorized administrator of Digital Commons @ University of South Florida. For more information, please contact digitalcommons@usf.edu. 


\title{
Evaluation of groundwater storage monitoring with the GRACE satellite: Case study of the High Plains aquifer, central United States
}

\author{
Gil Strassberg, ${ }^{1}$ Bridget R. Scanlon, ${ }^{1}$ and Don Chambers ${ }^{2}$ \\ Received 1 February 2008; revised 7 October 2008; accepted 8 January 2009; published 9 May 2009.
}

[1] Water scarcity is a critical issue in semiarid regions; however, regional groundwater monitoring is extremely limited. This study evaluates the ability of the GRACE satellites to monitor groundwater storage in the semiarid High Plains aquifer, United States $\left(450,000 \mathrm{~km}^{2}\right.$ area), which is subjected to intense irrigation. GRACE-derived terrestrial water storage (TWS) is highly correlated with the sum of soil moisture (SM) and groundwater storage (GWS) $(R=0.96$ for in situ measured SM from 78 stations and $R=0.95$ for simulated SM with the Noah land surface model with root-mean-square difference of $38 \mathrm{~mm}$ and $36 \mathrm{~mm}$, respectively). Correlation between seasonal GWS changes calculated from GRACE TWS minus SM and measured GWS $(\sim 1000$ wells per season) is also high $(R=0.73$ for in situ SM and $R=0.72$ for simulated SM). Variability in SM is mostly restricted to the upper $2 \mathrm{~m}$ of the soil. Monitored SM compared favorably with simulated SM $(R=0.82)$. Study results show the potential for using GRACE gravity measurements to monitor TWS and GWS over large semiarid regions subjected to intense irrigation.

Citation: Strassberg, G., B. R. Scanlon, and D. Chambers (2009), Evaluation of groundwater storage monitoring with the GRACE satellite: Case study of the High Plains aquifer, central United States, Water Resour. Res., 45, W05410, doi:10.1029/2008WR006892.

\section{Introduction}

[2] Variations in terrestrial water storage, including surface water, snow and ice, soil moisture, and groundwater, are essential for understanding a wide range of hydrologic, climatic, and ecologic processes and are important for water resources and agricultural management. Water scarcity is a global concern, with an estimated 1.1 billion people lacking access to clean water [World Health Organization, 2003]. Increasing demand for water requires more accurate information on water resources. While monitoring networks for precipitation and rivers exist in most regions, monitoring of subsurface water reservoirs (soil moisture and groundwater) is inadequate. However, groundwater represents a much larger fraction $(\sim 30 \%)$ of global fresh water resources than rivers $(\sim 0.006 \%)$ [Dingman, 2002]. In addition, depletion of groundwater resources has increased substantially in the last several decades, particularly in places where groundwater-based irrigation has expanded, such as the North China Plain and western India [Scanlon et al., 2007]. However, monitoring of groundwater storage in these regions is extremely limited. Lack of information on groundwater storage changes inhibits development and execution of effective water management plans. Many countries with severe groundwater depletion problems have limited information on spatial and temporal variability in

\footnotetext{
${ }^{1}$ Bureau of Economic Geology, Jackson School of Geosciences, University of Texas at Austin, Austin, Texas, USA.

${ }^{2}$ Center for Space Research, University of Texas at Austin, Austin, Texas, USA.
}

Copyright 2009 by the American Geophysical Union. 0043-1397/09/2008WR006892 groundwater storage [Shah et al., 2000], as monitoring networks are generally limited and it is difficult to regionalize point-based measurements. To improve water resources management it is critical to develop monitoring systems that provide accurate and timely information on the status of water reservoirs, including water in soil and aquifers.

[3] Satellites, in this case the Gravity Recovery and Climate Experiment (GRACE) satellite, have the potential to address the observational gap of monitoring regional water storage changes. The GRACE mission provides approximately monthly changes in terrestrial water storage (TWS) on the basis of measurements of the Earth's global gravity field [Tapley et al., 2004; Wahr et al., 2004]. TWS, as inferred from the gravity measurements, represents a vertically integrated measure of water storage that includes groundwater, soil moisture, surface water, snow and ice, and biomass. Therefore, in order to infer one component from total TWS (e.g., groundwater storage), other components (e.g., surface water, soil moisture) need to be measured or estimated. A number of studies have validated GRACEderived TWS with results from land surface models and with monitored soil moisture and groundwater storage changes. These studies showed that GRACE TWS can be used to evaluate land surface model simulations and to estimate changes in components of the water budget (e.g., evapotranspiration, soil moisture, groundwater, snow water, and basin discharge) within large basins [e.g., Rodell et al., 2004b; Syed et al., 2005; Yeh et al., 2006; Rodell et al., 2006; Niu and Yang, 2006; Hu et al., 2006; Swenson et al., 2008b]. These studies have mainly been conducted for large river basins in humid regions with shallow groundwater (e.g., Mississippi and Amazon River basins, Illinois aquifer). However, many of 


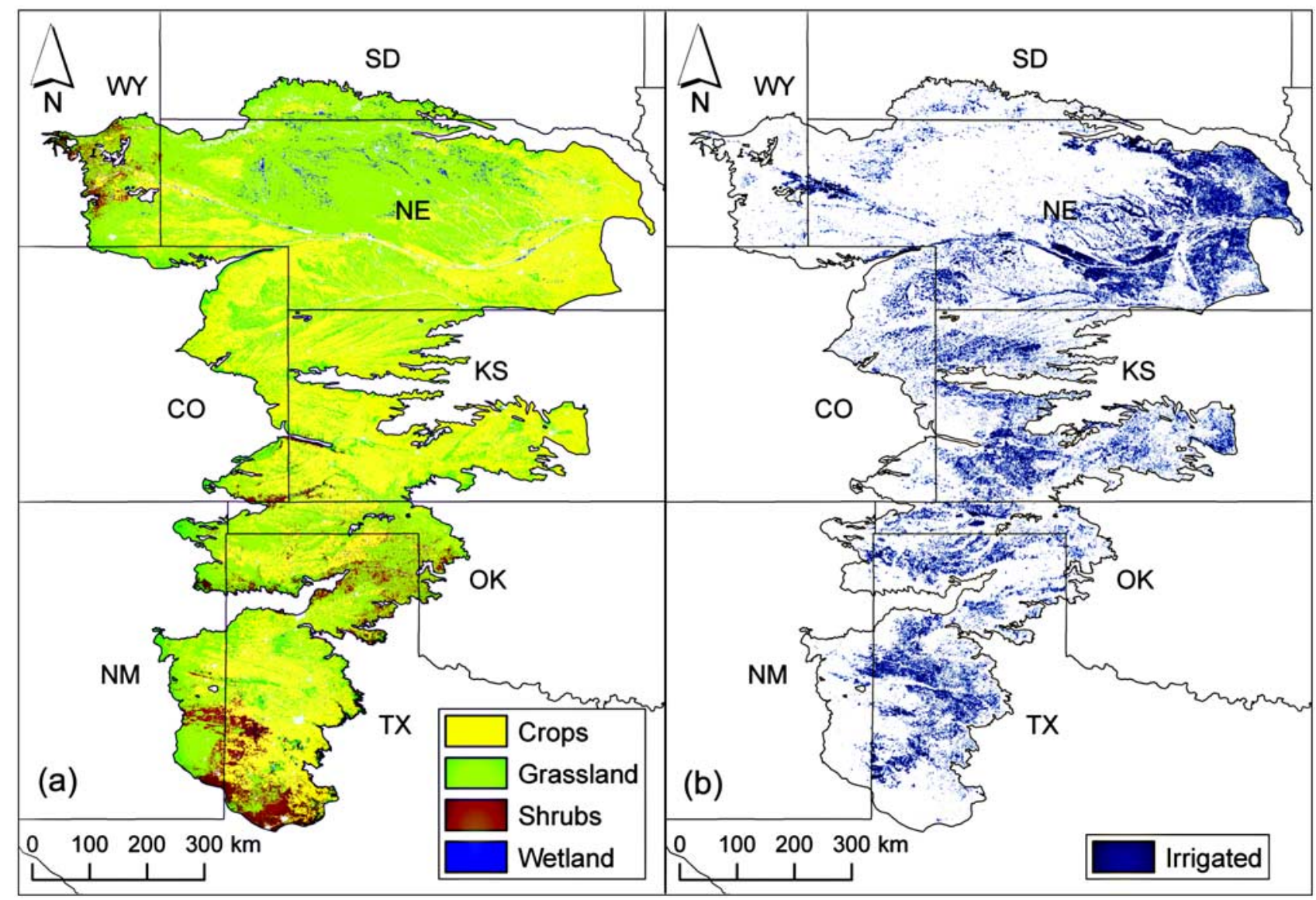

Figure 1. (a) Land cover over the High Plains aquifer based on the 2001 National Land Cover Database (NLCD) [Homer et al., 2007]. Grassland and crops are the major land cover types. (b) Irrigated areas over the High Plains aquifer [Qi et al., 2002].

the world's critical water resource problems are in basins in semiarid regions with typically deep water tables (tens of meters) and large groundwater level declines, primarily related to irrigated agriculture. The High Plains aquifer is representative of such an aquifer system in a semiarid region, where extensive irrigation has resulted in large-scale depletion of groundwater storage.

[4] The High Plains aquifer $\left(450,000 \mathrm{~km}^{2}\right)$, underlying eight states in the central United States, is a principal aquifer and a source of water for one of the major agricultural areas in the world (Figure 1). The aquifer is generally unconfined and consists of sediments of late Tertiary and Quaternary age. The Ogallala Formation (upper Tertiary) is the main geologic unit of the aquifer and consists of a heterogeneous sequence of sands, silts, clays, and gravels [Gutentag et al., 1984]. Saturated thickness of the aquifer ranges from 0 to $300 \mathrm{~m}$ (mean $60 \mathrm{~m}$ ), and water table depth ranges from 0 to $150 \mathrm{~m}$ (mean $30 \mathrm{~m}$ ) [Dennehy, 2000]. The climate of the region is mostly semiarid, with mean annual precipitation (P) ranging from $400 \mathrm{~mm}$ in the west to $600 \mathrm{~mm}$ in the east, and mean annual pan evaporation (PE) from 1,500 in the north to $2,700 \mathrm{~mm}$ in the south, greatly exceeding precipitation [Gutentag et al., 1984]. The High Plains region is also known as one of the largest agricultural areas of the world, with $175,000 \mathrm{~km}^{2}$ of cropland (Figure 1a). Because of the generally low $\mathrm{P} / \mathrm{PE}$ ratio, agriculture in the region is heavily dependent on irrigation, mainly from groundwater.
The large-scale irrigated area $\left(\sim 50,000 \mathrm{~km}^{2}\right.$, Figure $\left.1 \mathrm{~b}\right)$ represents $27 \%$ of irrigated land in the U.S. and accounts for $\sim 30 \%$ of groundwater used for irrigation in the U.S. [Dennehy, 2000]. As a result of this large-scale irrigation, groundwater levels in the aquifer have declined significantly. In response to these declines, the U.S. Geological Survey (starting in 1988), in cooperation with federal, state, and local agencies, began monitoring groundwater levels throughout the aquifer to assess annual groundwater level changes. The latest estimates (2005) showed that since predevelopment (1950s) groundwater levels have declined by an average of $3.9 \mathrm{~m}$ over the entire aquifer area, with some areas exhibiting declines of up to $84 \mathrm{~m}$ [McGuire, 2007]. Estimated annual groundwater withdrawals from the aquifer are $\sim 24 \mathrm{~km}^{3}$ in 2000 , with $\sim 97 \%$ of the water used for irrigation [Maupin and Barber, 2005]. This is equivalent to $54 \mathrm{~mm}$ of water over the entire aquifer area and $\sim 450 \mathrm{~mm}$ over irrigated areas. Therefore, most groundwater withdrawals are assumed to occur during the crop growing season, primarily during the summer. Amosson et al. [2003] estimated irrigation water demand for the southern part of the High Plains in Texas, using a water balance crop use approach. Their results showed that $\sim 95 \%$ of irrigation withdrawals should occur during the crop growing season from April through August.

[5] Since the inception of the GRACE mission, the High Plains aquifer has been proposed as an ideal location to 
validate GRACE-derived TWS changes because of the large aquifer area $\left(450,000 \mathrm{~km}^{2}\right)$ and because it is the most intensively monitored aquifer at this scale globally [National Research Council Committee on Earth Gravity From Space, 1997]. The large groundwater withdrawals for irrigation also provide a strong seasonal signal that should be detectable by GRACE. Strassberg et al. [2007] compared GRACE-derived seasonal TWS changes over the High Plains aquifer with simulated soil moisture (SM) and in situ measured groundwater storage (GWS) changes for the period from 2003 through 2005. The results show a good fit between GRACE-derived TWS and combined SM + GWS $(R=$ 0.82). This paper is an expansion of the previous study that includes a much more in-depth analysis of the use of GRACE data to monitor groundwater storage changes, a longer time period for comparison (2003-2006), an evaluation of the reliability of simulated soil moisture by comparison with in situ monitored soil moisture from an extensive network of soil moisture stations, and the most up-to-date release of GRACE data (release 04 versus release 03 in the previous study). The study includes a dense network of soil moisture stations (78 shallow $(\leq 1 \mathrm{~m})$ stations, and 13 deep $(\leq 7 \mathrm{~m})$ stations) and groundwater level changes (an average of 983 data points per season) covering the aquifer area. These groundbased monitoring networks are much denser than those used in most previous analyses. The availability of these data sets provides a unique opportunity to compare GRACE-derived TWS with in situ measurements of water storage in the soil and underlying aquifer over the large area.

[6] In this study seasonal terrestrial water storage changes derived from GRACE gravity measurements were compared with in situ measurements of soil moisture and groundwater levels. An extensive network of soil moisture stations and groundwater level measurements was used to derive in situ estimates of terrestrial water storage. Simulated soil moisture from a land surface model was also compared with in situ soil moisture measurements. This comparison is important to evaluate the reliability of simulated soil moisture. In many areas of the world monitoring of soil moisture and groundwater are limited, and in such cases the combination of GRACE-derived TWS and simulated soil moisture from a land surface model could be used to estimate regional groundwater storage changes. A unique aspect of this study is the comparison of GRACE-derived TWS in a semiarid region over a large aquifer with a deep groundwater table, where variability in groundwater storage is dominated by irrigation. The nature of the region, together with the large amount of available soil moisture and groundwater data, provides an ideal test bed to assess the applicability of GRACE data for monitoring groundwater storage changes.

\section{Data and Methods}

[7] TWS variations represent a vertically integrated measure of water storage changes that include soil moisture, groundwater, surface water, snow and ice, and biomass. A previous study of TWS changes in the High Plains showed that soil moisture and groundwater are the primary contributors to TWS variability and that variations in snow and ice, biomass, and surface water are relatively minor [Strassberg et al., 2007]. Therefore, in this study changes in TWS were assumed to be controlled primarily by soil moisture and groundwater.

$$
\Delta T W S=\Delta S M+\Delta G W S
$$

where $\Delta$ is change (e.g., monthly, seasonal, or annual changes), SM is soil moisture, and GWS is groundwater storage. SM in this context refers to volumetric soil moisture content, which is the volume of water stored within the soil column. If TWS and SM are known (e.g., from GRACE and from land surface model simulations, respectively) equation 1 can be reorganized so that GWS changes are estimated $(\triangle G W S=\Delta T W S-\triangle S M)$. In this study GRACE-derived TWS was compared with in situ and simulated SM combined with GWS changes derived from groundwater level measurements.

\subsection{GRACE Terrestrial Water Storage (TWS)}

[8] The GRACE satellites do not measure variations in water storage directly, but instead measure the Earth's gravitational field. Unlike most missions, the satellites themselves act as the measurement devices. The GRACE system consists of two chasing satellites (also called Tom and Jerry). When gravity increases, the leading satellite accelerates, before the second accelerates and catches up. Thus, gravity variations induce distance variations between the satellites. The GPS location of each satellite is precisely recorded, and a microwave ranging system measures changes in distance between the two satellites to within $10 \mu \mathrm{m}$. The GRACE project then uses measured variations in the range rate between the two satellites and other tracking data to estimate gravitational coefficients, along with other dynamical orbit parameters, in a least squares estimation to maximize the fit between a modeled orbit (based on gravitational potential) and the measurements [Bettadpur, 2007]. Estimations of the gravity field coefficients are made approximately every month to spherical harmonic degree and order 60. Spherical harmonics are twodimensional basis functions represented by Legendere polynomials and cosine and sine functions of order times the longitude. Like a Fourier series, the sum of the spherical harmonic series represents a sum of sinusoidal functions with wavelengths from the longest (the circumference of the Earth, $\sim 40,000 \mathrm{~km})$ to the smallest $(\sim 40,000 \mathrm{~km} /$ maximum degree), which is $\sim 600 \mathrm{~km}$ in this case. Wahr et al. [1998] detailed the methodology for converting time-variable gravity field coefficients to maps of surface mass density (water storage anomalies) on the basis of the assumption that for periods less than several hundred years the primary cause of temporal changes in the Earth's gravity field is movement of water mass within the Earth's relatively thin fluid envelope. One problem with using GRACE data for this purpose is that the gravity coefficients are significantly more accurate for long wavelengths than for short wavelengths; therefore, they must be smoothed and hence represent average water storage over some spherical disk [e.g., Wahr et al., 1998]. Swenson and Wahr [2002] expanded this smoothing idea to create special smoothing functions to obtain the "best" estimate of water storage variation from GRACE for any defined storage area, such as a river basin or aquifer, on the basis of the shape of the storage area (which does not have to be regular), an estimate of GRACE errors as a function of 


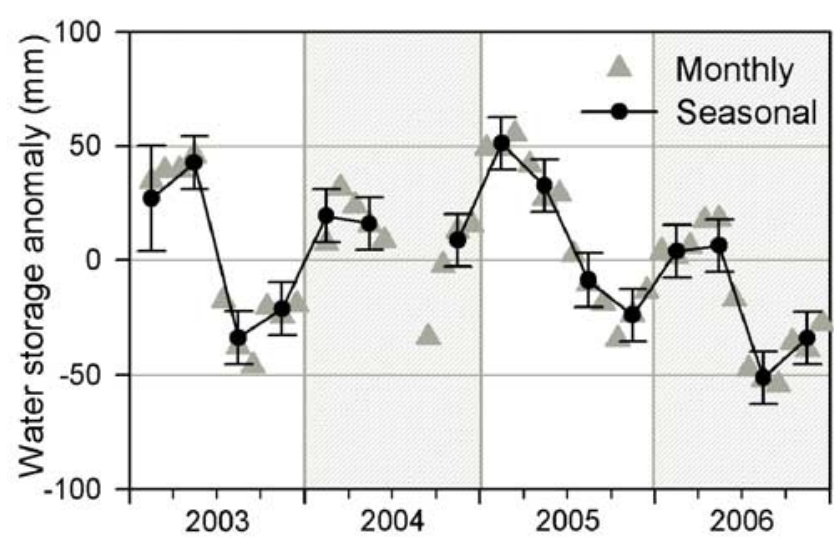

Figure 2. GRACE-derived terrestrial water storage (TWS) anomalies over the High Plains aquifer area. Monthly TWS anomalies were aggregated into seasonal anomalies to be compared with monitored/modeled soil moisture and monitored groundwater storage.

spherical harmonic degree, and the mean variability of hydrologic variations outside of the region of interest. Swenson and Wahr [2002] also suggested a method to derive a scaling parameter to restore power attenuated by the smoothing process, again, on the basis of an approximation of the true average signal inside the area compared with the recovered signal after smoothing.

[9] We have modified the method of Swenson and Wahr [2002] in this application, by using full month-to-month variations in modeled water storage anomalies from the Global Land Data Assimilation System (GLDAS)/Noah hydrologic model [Rodell et al., 2004a] for January 2003 until December 2006 to derive the optimal kernel. After converting GLDAS/Noah data to equivalent gravity field coefficients, we processed the model data with a series of smoothed averaging kernels (ranging from no smoothing to smoothing with a radius of $1000 \mathrm{~km}$ ) truncated to degree and order 60 and compared the results with the "true" average over the High Plains aquifer with no smoothing or truncation. A linear scaling parameter was estimated to restore power from the smoothed coefficients to the "true" average, and then the standard deviation of the differences was calculated. This was then added to the standard deviation of the GRACE errors at the same smoothing [e.g., Swenson and Wahr, 2002], and a minimum was computed. The minimum was found at a smoothing radius of $\sim 500 \mathrm{~km}$.

[10] The scaling factor calculated from the GLDAS/Noah simulation at this smoothing interval was applied to the GRACE data after applying the smoothed kernel. Level 2 release 04 (RL04) gravity field coefficients from the Center for Space Research (CSR) were used. The coefficients have been adjusted by replacing monthly degree 2 order 0 terms with those from a satellite laser ranging (SLR) analysis [Cheng and Tapley, 2004], after removing the effects of the same atmosphere/ocean model used in the GRACE processing. A new monthly geocenter estimate calculated by Swenson et al. [2008a] on the basis of an ocean model and GRACE data, was added. The data were corrected for glacial isostatic adjustment (GIA) on the basis of the model by Paulson et al. [2007]. In this analysis, we have used all available months except January 2003 and January 2004 (because of less than 1-month coverage) and August and September 2004 (because of poor spatial coverage due to the satellite's ground track during the month). No data were collected during June 2003, which means no gravity solution exists for this month.

[11] Estimated uncertainty in the monthly water storage anomalies is $21 \mathrm{~mm}$ of water for measurements after February 2003 and $35 \mathrm{~mm}$ for observations before March 2003, with the greater error arising from higher GRACE errors. Errors were reduced with averaging of TWS anomalies, assuming that errors in the monthly TWS are not correlated (because each monthly solution is processed separately):

$$
\delta_{N}=\delta_{i} / \sqrt{N}
$$

where $\delta_{N}$ is estimated uncertainty in TWS averaged over $\mathrm{N}$ months, and $\delta_{i}$ is estimated uncertainty in a 1-month anomaly. Using equation (2) for seasonal (3-month) periods, estimated uncertainty in GRACE TWS is $12.1 \mathrm{~mm}$ except for the 2003 winter period (January-March 2003), where estimated uncertainty is $20.2 \mathrm{~mm}$. Monthly TWS anomalies were averaged to calculate seasonal (January-March, April-June, July-September, and October-December) anomalies (Figure 2).

\subsection{Soil Moisture}

[12] In this study soil moisture analysis served two purposes: (1) in situ soil moisture data were combined with in situ groundwater level measurements to compare with GRACE TWS and (2) simulated SM changes from a land surface model were compared with in situ data to evaluate the applicability of using simulated SM changes instead of in situ data. Comparison of measured and simulated soil moisture allows the reliability of using simulated soil moisture for estimating regional GWS from GRACE to be evaluated. This comparison is important for regions where measured soil moisture data are not available.

[13] In situ soil moisture measurements include data from 78 monitoring stations with shallow profiles $(0.75-1 \mathrm{~m}$, Figure 3). Data were obtained from a number of monitoring networks, including the West Texas Mesonet (www.mesonet. ttu.edu), the Oklahoma Mesonet (www.mesonet.org), the High Plains Regional Climate Center (www.hprcc.unl.edu), the Soil Climate Analysis Network (SCAN, www.wcc. nrcs.usda.gov/scan), and the Atmospheric Radiation Measurement Program Soil Water and Temperature System (ARM-SWATS, www.arm.gov). In addition to the shallow profiles, data were obtained from 13 stations with deeper profiles $(1.75-7 \mathrm{~m})$ across the aquifer area and 18 stations (3 $\mathrm{m}$ depth) at an experimental site in the Nebraska Sand Hills [Wedin et al., 2007].

[14] For comparison with GRACE TWS, depth-integrated SM storage anomalies were required. As most of the SM measurements are shallow $(\leq 1 \mathrm{~m})$, it was difficult to capture the full amplitude of SM anomalies only on the basis of the shallow measurements. Also, simulated SM from the Noah land surface model [Ek et al., 2003] was used in the analysis. Forcing and parameterization of the model were based on data from the North American Land Data Assimilation System (NLDAS) [Cosgrove et al., 2003]. The model simulated SM in the top $2 \mathrm{~m}$ of the soil column. Thus, to compare in situ 


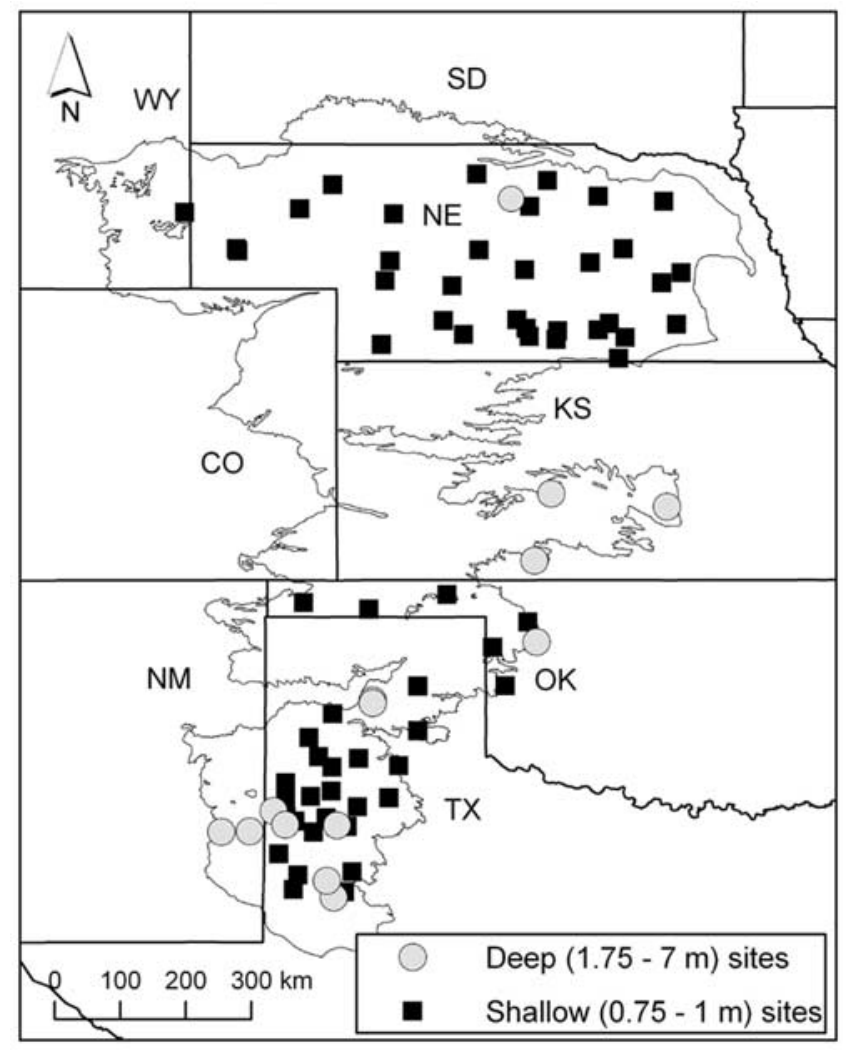

Figure 3. Location of soil moisture monitoring stations. Squares represent sites with shallow $(0.75-1 \mathrm{~m})$ profiles, and circles represent sites with deep $(1.75-7 \mathrm{~m})$ profiles.

SM measurements with simulated SM, it was necessary to "upscale" the shallow SM measurements to $2 \mathrm{~m}$ depth. Upscaling the shallow data $(\leq 1 \mathrm{~m})$ was done using SM data from deeper stations $(1.75-7 \mathrm{~m})$.

[15] For each site depth-integrated SM was calculated for 1,2 , and $4 \mathrm{~m}$ depths. Data from most sites were provided as volumetric soil moisture content, and at sites where matric potential was measured, it was converted to volumetric soil moisture content using a van Genuchten retention function for the appropriate soil texture [van Genuchten, 1980]. Parameters for the retention functions were estimated using the Rosetta pedotransfer software [Schaap et al., 2001] on the basis of site specific data on soil texture and bulk density. For each integration depth, SM anomalies over the study period were calculated. Then two factors were used to analyze variations in SM with depth: (1) the standard deviation (SD) of the anomalies at different depths, and (2) a calculated "fit factor," which is a multiplier used to scale SM variations while minimizing the root-meansquare difference (RMSD) between two data sets (Figure 4).

[16] The Nebraska Sand Hills region differs hydrologically from much of the High Plains because of the high sand content in soils, close to $100 \%$ in some locations (Figure 5a). SM variability in the Sand Hills extends to depths of at least $3 \mathrm{~m}$ [Wedin et al., 2007]. Variability in SM at depths $>3 \mathrm{~m}$ was modeled using an exponential function $\operatorname{SM}(z)=$ $\mathrm{SM}_{0} * \exp (-z / b)$, following Swenson et al. [2008b], because there are no SM measurements at these depths. Using measurements to a depth of $3 \mathrm{~m}$, a least squares fit was used to estimate the parameters in the exponential model ( $b$ and
$\mathrm{SM}_{0}$ ). The model was then used to estimate fit factors to a depth of $10 \mathrm{~m}$. The State Soil Geographic Database (STATSGO, http://soildatamart.nrcs.usda.gov) hydrologic group classification was used to categorize soils into four main hydrologic infiltration groups: (1) high, (2) moderate, (3) slow, and (4) very slow infiltration rates (Figure $5 \mathrm{~b}$ ). The study area was divided into a $1 \times 1$ degree mesh, which was used to aggregate point measurements and upscale point data to spatial averages. Numeric values were assigned to the hydrologic group categories ( $1=$ high infiltration to $4=$ very slow infiltration), and the average hydrologic group per cell in the mesh was calculated (Figure 5c).

[17] For each $1 \times 1$ degree cell in the mesh, the mean SM anomaly for an integrated depth of $1 \mathrm{~m}$ was calculated by averaging anomalies from all stations within a cell. Then mean anomalies in each cell were upscaled on the basis of the appropriate fit factor. An area-weighted anomaly was calculated for the entire study area. The calculated SM anomalies were compared with depth-integrated simulated SM from the Noah land surface model.

\subsection{Groundwater Storage}

[18] Groundwater storage variations were calculated from field measurements of groundwater levels throughout the

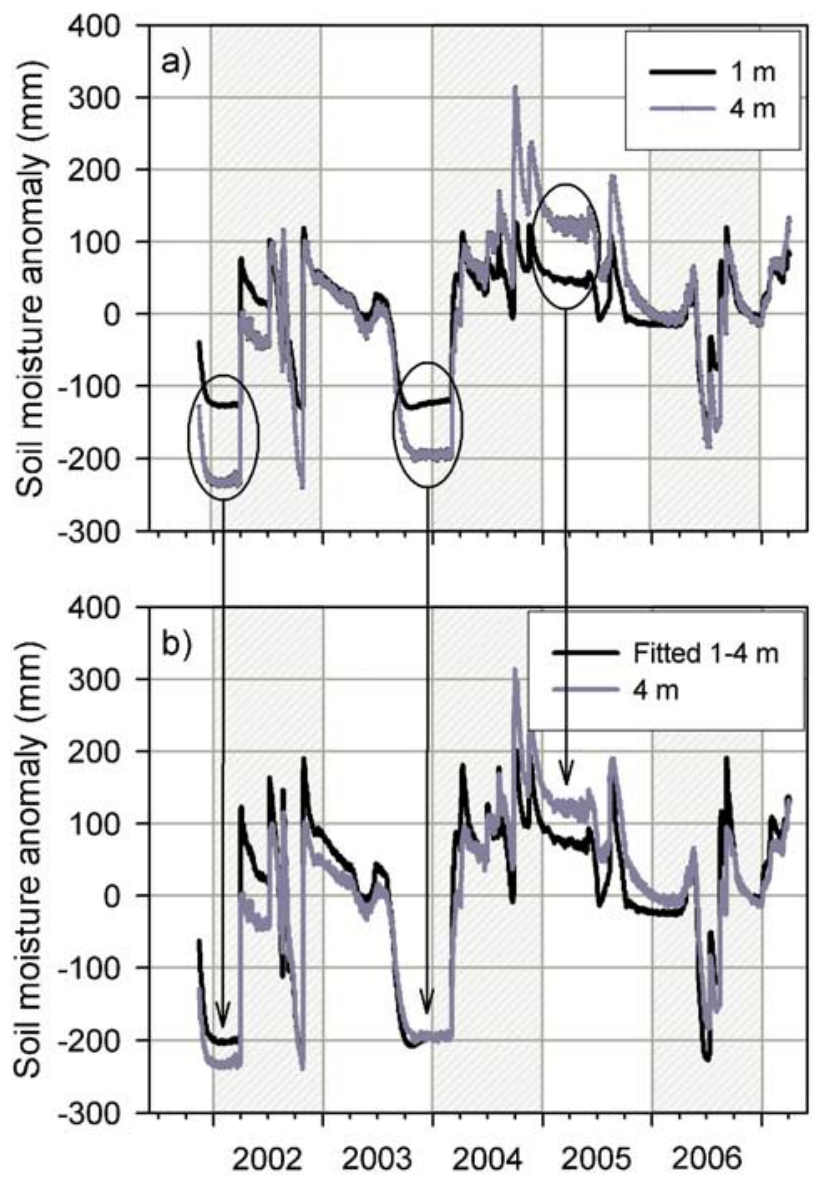

Figure 4. Fit factors used to estimate variability of SM for different integration depths. (a) SM anomalies at depths of 1 and $4 \mathrm{~m}$ and (b) $1 \mathrm{~m}$ data fitted to $4 \mathrm{~m}$ data. In this example, a fit factor of 1.6 was used to minimize the RMSD between the two time series. Circled areas show the fitting process. 

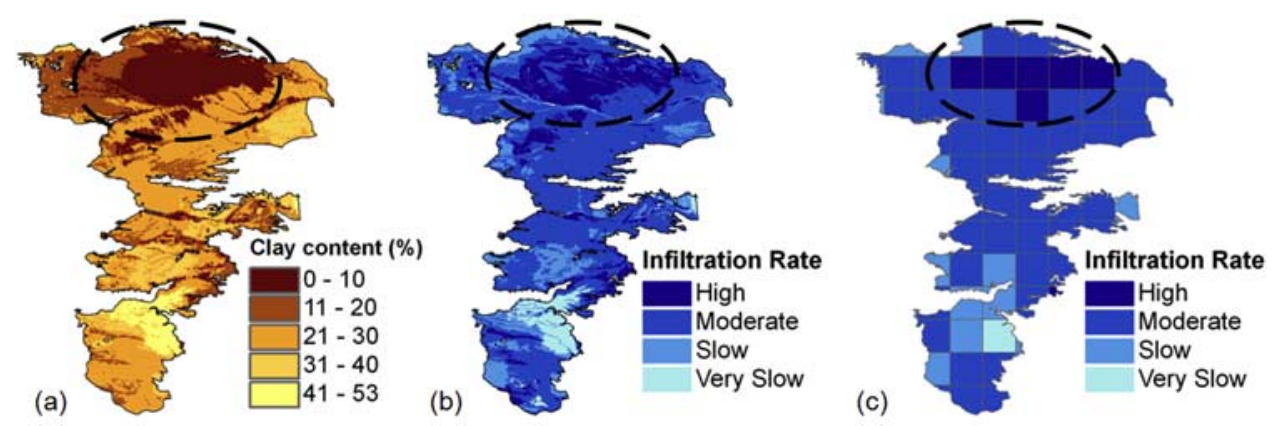

Figure 5. Data from STATSGO soil survey database used to distinguish areas with high infiltration rates in the Nebraska Sand Hills (circled) and to calculate appropriate fit factors. (a) Clay content (\%) from STATSGO soil survey, (b) hydrologic group categories, and (c) average hydrologic group for each $1 \times 1$ degree cell. The cells were used to spatially aggregate point observations.

aquifer. Groundwater level measurements were obtained from federal and state databases, including the U.S. Geological Survey (USGS) National Water Information System (NWIS, http://waterdata.usgs.gov), the Texas Water Development Board (http://www.twdb.state.tx.us), and the Kansas Geological Survey (www.kgs.ku.edu). Groundwater level changes were calculated for each well by first calculating the mean water level in each season (January-March, April-June, July-September, and October-December). Then groundwater level changes were calculated as the difference between groundwater levels in two consecutive seasons. Seasonal averaging periods (instead of monthly) were used for the groundwater data because this substantially increased the number of available data points.

[19] Seasonal groundwater level changes were calculated from January 2003 through December 2006. Groundwater level changes were calculated for 1989 wells with at least one groundwater level measurement in two consecutive seasons (Figure 6a). The number of groundwater level data points for each season varied from 760 to 1230 with an average of 983 data points. To eliminate errors in groundwater level measurements that could be attributed to measurement errors or measurements taken in active pumping zones, data were filtered to exclude extreme changes. Daily groundwater level records from 75 wells in the USGS database showed that the seasonal amplitude of groundwater levels is $\leq 4.6 \mathrm{~m}$ (15 feet) in $97 \%$ of wells. Thus, groundwater level changes $\geq 4.6 \mathrm{~m}$ were not included in the analysis. Groundwater level changes were spatially aggregated and regionalized to calculate a single representative value for the High Plains. First, groundwater level anomalies were averaged over a $1 \times 1$ degree mesh, where each cell of the mesh was assigned the mean value of all wells within it (Figure 6c). Then, an area-weighted average was calculated from the cell values.

[20] Groundwater level changes were converted to groundwater storage changes by multiplying water level changes by the specific yield of the aquifer. Specific yield in the High Plains aquifer ranges from 0 to $30 \%$. For this study an area-weighted average specific yield of 0.15 was used [Gutentag et al., 1984].

\section{Results and Discussion}

\subsection{Soil Moisture}

[21] Results of in situ SM analysis show that variability in SM is mostly limited to the upper $2 \mathrm{~m}$ of the soil profile, especially under natural grassland and shrubland ecosystems and rain-fed (nonirrigated) cropland. Comparison of the SD and fit factors calculated for different integration depths (Tables 1a and $1 \mathrm{~b}$ ) reveals that almost $100 \%$ of the variability under these settings is contained within the upper $2 \mathrm{~m}$ of the soil column, while under irrigated areas variability in the upper $2 \mathrm{~m}$ accounts for 76 to $98 \%$ of the total variability (depending on the estimation method). Thus, total water storage variations in the soil column can gener-

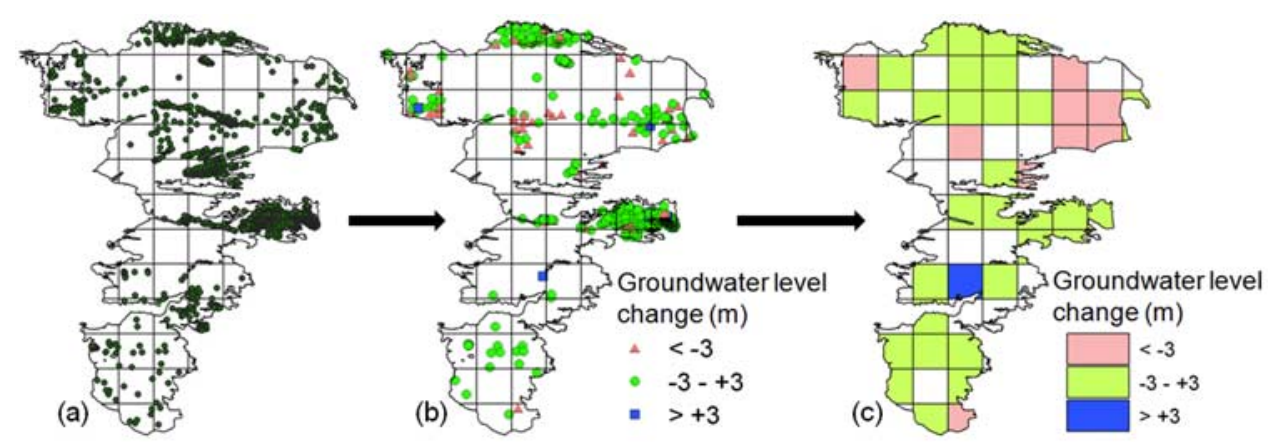

Figure 6. Process of calculating groundwater level changes. (a) Location of wells where groundwater level changes were calculated, (b) example of groundwater level changes between spring (April-June) and summer (July-August) 2003, and (c) groundwater level changes spatially aggregated over a $1 \times 1$ degree mesh. 
Table 1a. Standard Deviations of Depth-integrated Soil Moisture for 1, 2, and $4 \mathrm{~m}$ Depths

\begin{tabular}{lcccc}
\hline & \multicolumn{2}{l}{ Mean Standard Deviation for Different Integration Depths } \\
\cline { 2 - 5 } & $1 \mathrm{~m}$ & $2 \mathrm{~m}$ & $4 \mathrm{~m}$ & $\begin{array}{c}\text { Ratio of SD 2 m } \\
\text { to SD 4 m }\end{array}$ \\
\hline Rain fed & 46.0 & 66.3 & 67.2 & $99 \%$ \\
Irrigated & 54.2 & 71.4 & 93.6 & $76 \%$ \\
Natural & 72.7 & 104.9 & 106.9 & $98 \%$ \\
\hline
\end{tabular}

ally be represented using an integration depth of $2 \mathrm{~m}$ because this captures most (close to $100 \%$ ) of the variability. An average fit factor of about 1.3 was used to upscale $1 \mathrm{~m}$ depth-integrated anomalies to $2 \mathrm{~m}$ depth in most of the High Plains, with the exception of the Nebraska Sand Hills region, where variability in SM is measured to depths of at least $3 \mathrm{~m}$.

[22] In the Sand Hills region the average ratio of SD of anomalies for integration depths of 2 and $3 \mathrm{~m}$ (SD $2 \mathrm{~m} / \mathrm{SD}$ $3 \mathrm{~m}$ ) is 0.73 , which indicates that SM variability is not fully contained within the upper $2 \mathrm{~m}$ of the soil column. The average fit factor calculated for upscaling SM anomalies from 1 to $2 \mathrm{~m}$ is 1.6. The modeled fit factors (using an exponential function) showed that fit factors increase to a maximum of 2.5, with a fit factor of 2.2 at a depth of $4 \mathrm{~m}$. Thus, upscaling depth-integrated SM anomalies to $4 \mathrm{~m}$ captures $\sim 90 \%$ of the SM variability in the Nebraska Sand Hills region. Although variability in SM with depth is somewhat different in the Nebraska Sand Hills, the impact of this region on the entire High Plains SM estimate is relatively minor because of the area of the Sand Hills $\left(50,000-60,000 \mathrm{~km}^{2}, 11-13 \%\right.$ of the aquifer area). Varying the fit factor over the Sand Hills area between 1.3 and 2.2 changed the RMSE with the reference simulated SM by $\leq 2 \%$.

[23] In situ derived SM anomalies compared well with SM anomalies simulated by the Noah land surface model $(\mathrm{R}=0.82)$, both in amplitude and timing of variations (Figure 7). SM shows somewhat cyclical variation throughout the study period (2003-2006), with maxima during the spring and minima during the fall/winter. Elevated precipitation from September through November 2004 (175\% of long-term mean) explains the SM accumulation during the winter of 2004 and into the winter and spring of 2005.

\subsection{Groundwater Storage}

[24] Annual GWS measurements from field campaigns (published annually by the USGS) provide an excellent benchmark for comparison with seasonal GWS changes

Table 1b. Average Fit Factors for Upscaling Data Between 1 and 2, 2 and 4 , and 1 and $4 \mathrm{~m}$

\begin{tabular}{lcccc}
\hline & \multicolumn{3}{c}{ Mean Fit Factor } & \\
\cline { 2 - 4 } & $\begin{array}{c}\text { Factor 1, } \\
1 \text { to 2 m }\end{array}$ & $\begin{array}{c}\text { Factor 2, } \\
2 \text { to 4 m }\end{array}$ & $\begin{array}{c}\text { Factor 3, } \\
1 \text { to 4 m }\end{array}$ & $\begin{array}{c}\text { Ratio of Fit } \\
\text { Factors 1 to 3 }\end{array}$ \\
\hline Rain fed & 1.37 & 1.01 & 1.36 & $101 \%$ \\
Irrigated & 1.25 & 1.17 & 1.27 & $98 \%$ \\
Natural & 1.26 & 1.02 & 1.28 & $98 \%$ \\
\hline
\end{tabular}

estimated in this study (described in section 2.3), although the comparison is limited to annual (winter-to-winter) variation as groundwater levels are measured during the winter/spring period when groundwater levels have recovered from summer drawdown and have reached a static level. There are three winter-to-winter periods from January 2003 through December 2006 for which GWS changes were calculated (Figure 8). Although published data are only available for two of the three periods (2003-2004 and 2004-2005), interannual variations in GWS from the measured data are similar to those calculated in this study.

[25] Comparison of annual GWS changes with the storage changes published by the USGS provides confidence in our analysis of GWS changes on interannual time scales. However, seasonal GWS anomalies may be overestimated in our analysis, especially summer drawdown. This overestimation could result from bias in sampling locations because many of the wells monitored during the summer season are close to irrigated areas where drawdown is expected. Winter-to-summer changes in storage range from 67 to $119 \mathrm{~mm}$ (mean $98 \mathrm{~mm}$; Figure 8). This is almost double the groundwater withdrawals estimated by Maupin and Barber [2005], which is $53 \mathrm{~mm}$ (equivalent to $24 \mathrm{~km}^{3}$ ).

\subsection{Comparison of GRACE-Derived TWS and GWS}

[26] Overall, GRACE-derived TWS compared well with TWS calculated as SM + GWS (including in situ SM and simulated SM), both in magnitude and in timing of peaks (Figure 9). Both GRACE and measured TWS time series exhibit a seasonal cycle, with maximum storage in winter and minimum in summer/fall. TWS estimated as SM + GWS is highly correlated with GRACE-derived TWS $(R=$ 0.96 and $\mathrm{p}=2 \mathrm{E}-8$ for in situ SM; $R=0.95$ and $p=6 \mathrm{E}-8$ for simulated SM). GRACE-derived TWS showed lower variability, with a maximum amplitude of $75 \mathrm{~mm}$, while TWS calculated as SM + GWS had a maximum amplitude of $150 \mathrm{~mm}$. The RMSD between GRACE-derived TWS and TWS calculated from in situ SM measurements is $38 \mathrm{~mm}$ (Figure 9a), while that based on simulated SM is $36 \mathrm{~mm}$ (Figure 9b). Some of the differences between the estimates may be explained by overestimation of measured GWS

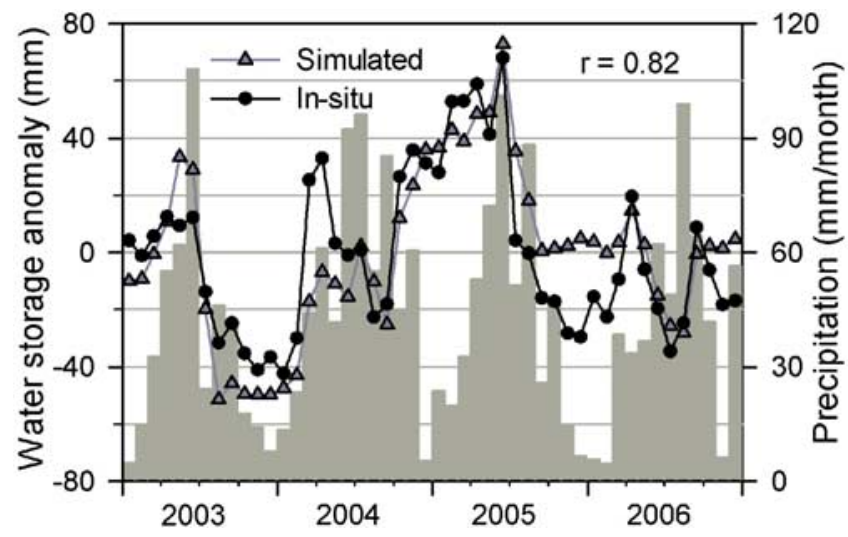

Figure 7. Monthly SM anomalies over the High Plains aquifer. Data represent vertically integrated SM to a depth of $2 \mathrm{~m}$ ( $4 \mathrm{~m}$ for the Nebraska Sand Hills region). The site data are spatially aggregated to represent a weighted average value for the aquifer area. 


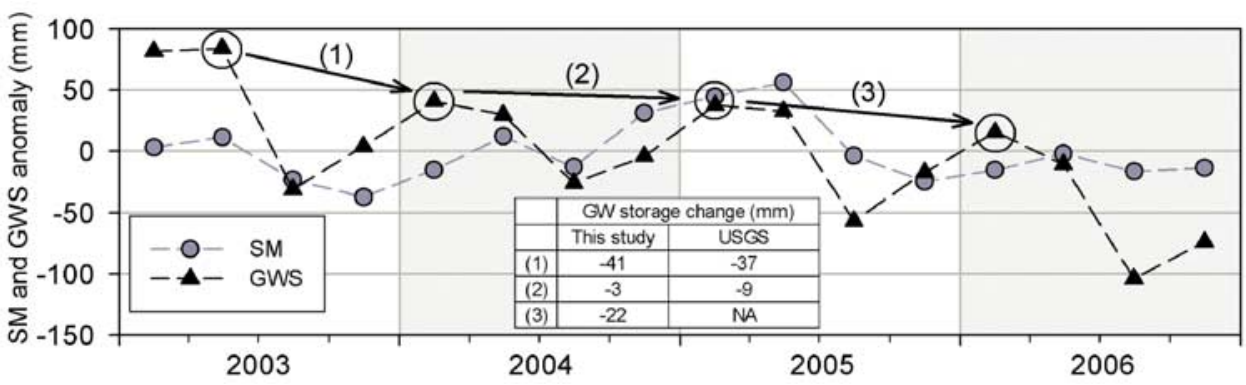

Figure 8. Seasonal GWS and SM anomalies over the High Plains aquifer. Circles and arrows show interannual winter-to-winter changes that were compared with GWS changes published by the USGS [McGuire, 2007].

declines in the summer. Other errors that could contribute to the difference include leakage of GRACE TWS signal from areas outside the High Plains aquifer, errors in SM and GWS introduced because of spatial aggregation of point measurements, and the use of an average specific yield to calculate groundwater storage changes.

[27] Grace-derived GWS changes calculated from TWS minus SM agreed well with estimates based on in situ groundwater level measurements, both in magnitude and timing of peaks $(R=0.73$ and $p=0.002$ for in situ SM, $R=$ 0.72 and $p=0.002$ for simulated SM) (Figure 10). In situ GWS calculated from groundwater level changes showed higher variability than GWS calculated from TWS minus SM, especially during summer when stronger declines were estimated from field measurements. The standard deviation (SD) of in situ GWS is $52 \mathrm{~mm}$, much larger than the SD of GWS calculated from TWS minus SM $(21 \mathrm{~mm}$ for in situ SM, $28 \mathrm{~mm}$ for simulated SM).

[28] GWS results were compared with annual changes published by the USGS and with those calculated as
GRACE-derived TWS minus SM (Table 2). USGS estimates for 2003-2004 and 2004-2005 are similar in direction (decrease in GWS) and in magnitude to changes calculated from in situ GWS in this study. Annual (winterto-winter) GWS changes calculated from groundwater level measurements do not agree with annual changes calculated as TWS minus SM. For the 2003-2004 period in situ data and USGS data show a decrease in groundwater storage, while GWS calculated as TWS minus SM showed an increase in GWS. For the 2004-2005 period GWS changes calculated as TWS minus SM showed a decrease in storage, (28.6 $\mathrm{mm}$ for in situ SM, and $43.7 \mathrm{~mm}$ for simulated SM) while the USGS and GWS analysis showed a decrease of $9.1 \mathrm{~mm}$ and $3.0 \mathrm{~mm}$, respectively. For the 2005-2006 period, in situ GWS analysis shows a decrease in storage (22.2 mm), while GWS calculated as TWS minus SM varied between an increase of $13.2 \mathrm{~mm}$ for in situ soil moisture to a decrease of $10.0 \mathrm{~mm}$ for simulated SM. This difference is attributed to the large discrepancy between in situ and

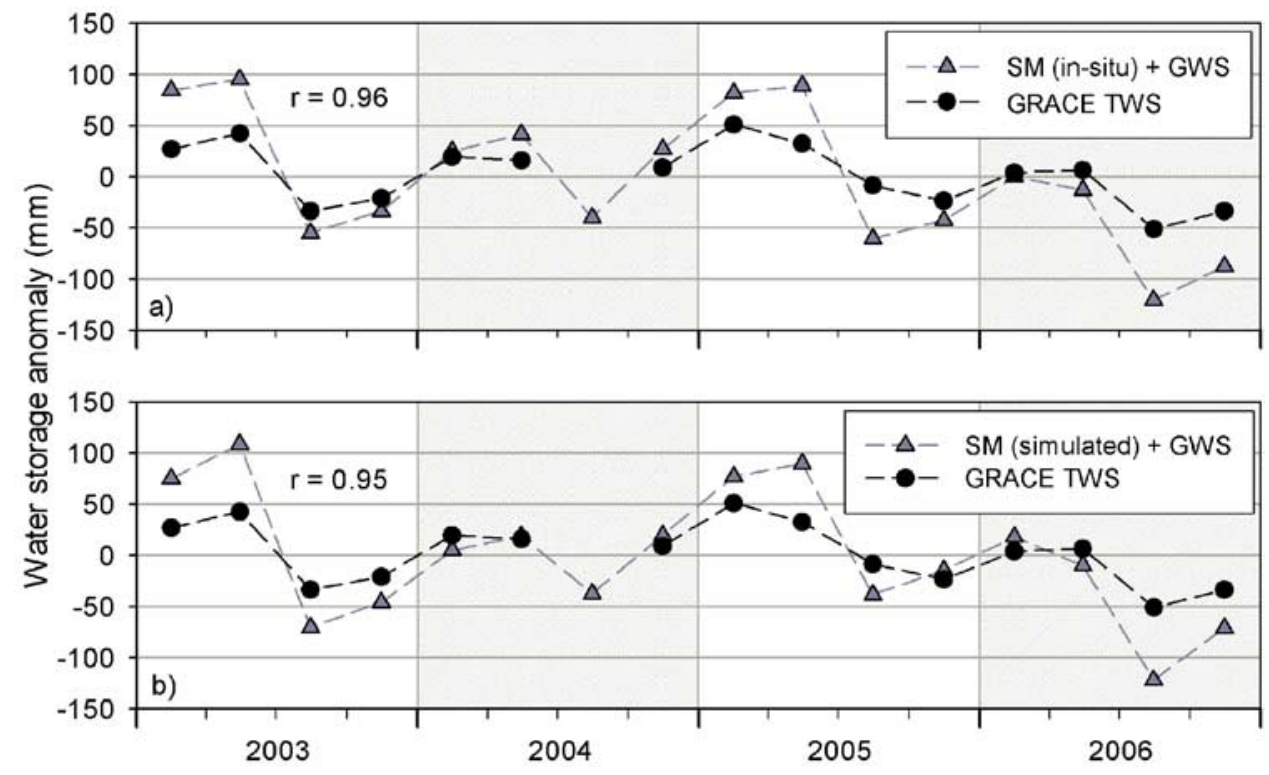

Figure 9. Comparison of GRACE-derived TWS with TWS calculated from (a) in situ SM plus GWS and (b) simulated SM plus GWS. 


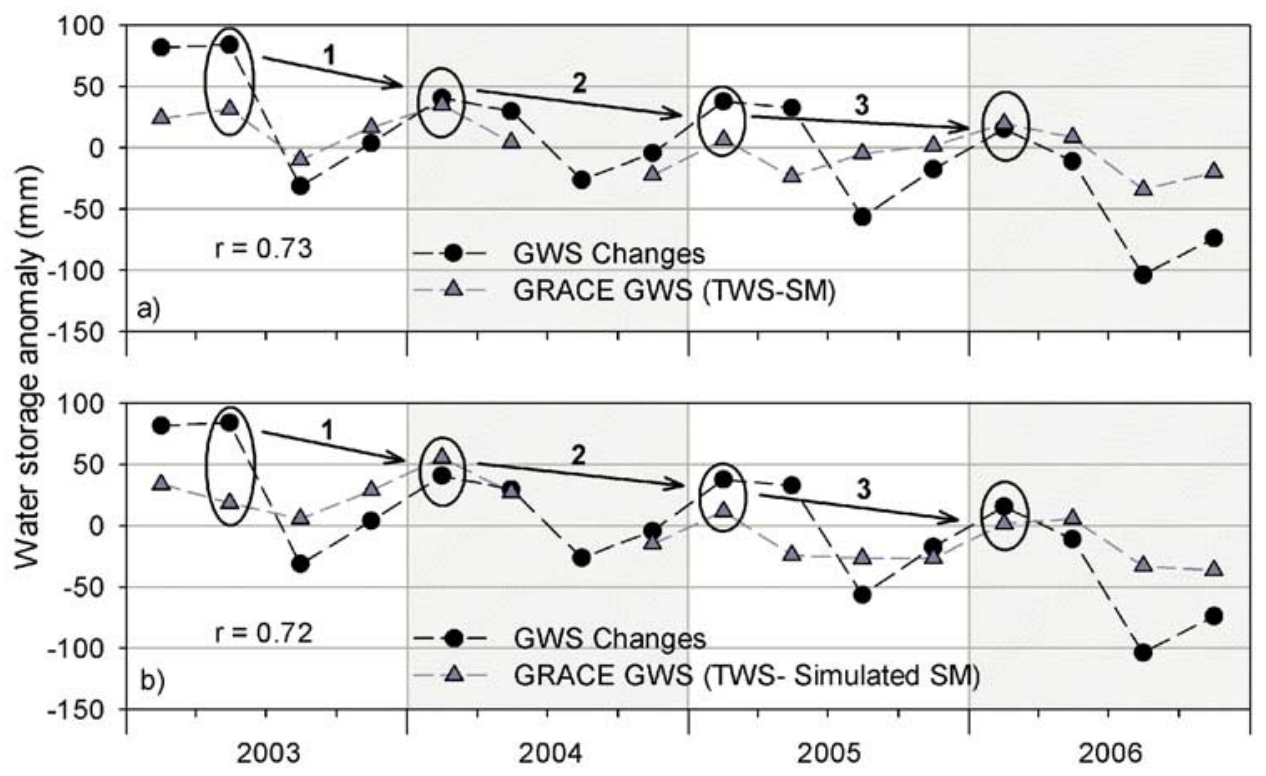

Figure 10. Anomalies in GWS from GRACE (TWS minus SM) compared with in situ GWS. (a) Soil moisture derived from in situ measurements and (b) soil moisture derived from Noah land surface model. Circles and arrows represent annual (winter-to-winter) changes, which were compared with USGS published data in Table 2.

simulated SM during the summer and fall of 2005 (see Figure 7).

\section{Summary and Conclusions}

[29] This study presents a comparison of GRACEderived TWS and GWS with in situ measurements of SM and groundwater levels in the High Plains aquifer $\left(450,000 \mathrm{~km}^{2}\right.$ area), which represents a semiarid region with deep groundwater (mean $30 \mathrm{~m}$ ) and strong seasonal groundwater storage changes resulting from intense irrigation.

[30] Monitored SM in deep $(1.75-7 \mathrm{~m})$ soil profiles showed that almost $100 \%$ of SM variability is in the upper $2 \mathrm{~m}$ of the soil column in natural ecosystems and rain-fed (nonirrigated) cropland throughout the High Plains. Even in irrigated areas $76 \%$ to $98 \%$ of SM variability is within the upper $2 \mathrm{~m}$. Monitored SM (after spatial aggregation) compared favorably to simulated SM from the Noah land surface model $(R=0.82)$, with similar magnitude of peaks and timing of changes. This comparison validates the applicability of land surface models for estimating SM variability over large areas with deep water tables, such as the High Plains aquifer.

[31] Grace-derived TWS is highly correlated with TWS derived from in situ soil moisture and groundwater level measurements $(R=0.96$, RMSD $=38 \mathrm{~mm}$ for in situ SM and $R=0.95$, RMSD $=36 \mathrm{~mm}$ for simulated $\mathrm{SM}$ ) in the High Plains aquifer. The two TWS signals agree both in magnitude and timing of peaks capturing maxima in TWS in winter-spring and minima during the summer. Seasonal variations in GWS calculated from groundwater level measurements are highly correlated with GWS calculated as GRACE TWS minus SM $(R=0.73$ for in situ SM, and $R=0.72$ for simulated SM). Comparison of annual (winter- to-winter) GWS changes estimated as TWS minus SM do not agree with annual GWS changes from measured data.

[32] Good agreement between GRACE-derived TWS and in situ measurements of SM and groundwater validates the potential for using GRACE gravity measurements to infer variability in TWS over large areas. In addition, good correspondence between GWS calculated as GRACE TWS minus SM and GWS estimated from groundwater level measurements from the intensively monitored High Plains aquifer demonstrates the potential for using GRACEderived TWS and measured or simulated SM to monitor GWS changes and aquifer depletion over large areas (hundreds of square kilometers) in semiarid regions subjected to intensive irrigation pumpage. The potential for using GRACE to monitor TWS and components of the hydrologic cycle is expected to improve over time as future advances in GRACE processing improve the spatial and

Table 2. Comparison of Annual Winter-to-Winter Groundwater Storage Changes ${ }^{\mathrm{a}}$

\begin{tabular}{|c|c|c|c|c|}
\hline \multirow[b]{2}{*}{ Period } & \multicolumn{4}{|c|}{ GWS Change (mm) } \\
\hline & USGS & $\begin{array}{l}\text { In situ } \\
\text { GWS }\end{array}$ & $\begin{array}{c}\text { TWS } \\
\text { Minus in Situ SM }\end{array}$ & $\begin{array}{c}\text { TWS } \\
\text { Minus Simulated SM }\end{array}$ \\
\hline $2003-2004$ & -36.6 & -43.2 & 3.8 & 37.1 \\
\hline $2004-2005$ & -9.1 & -3.0 & -28.6 & -43.7 \\
\hline $2005-2006$ & NA & -22.2 & 13.2 & -10.0 \\
\hline
\end{tabular}

${ }^{\mathrm{a}}$ The second column shows groundwater storage (GWS) changes published by USGS [McGuire, 2007]. In situ GWS changes were estimated from field measurements (described in section 2.3). NA means not available. The fourth column shows changes calculated by subtracting in situ SM from GRACE-derived TWS, and the fifth column is the same as the fourth but with simulated SM. The time series are also shown in Figure 10. 
temporal resolution of TWS changes, leading to more accurate and detailed monitoring of TWS.

[33] Acknowledgments. Funding for this study was provided by NASA (grant NNX08AJ84G) and the Jackson School of Geosciences at the University of Texas at Austin. The authors would like to thank the West Texas Mesonet, Oklahoma Mesonet, High Plains Regional Climate Center, National Water and Climate Center, and David Wedin for making available soil moisture measurements for this study. We also thank the NASA Goddard Space Flight Center, SAIC, Hydrological Sciences Branch for providing simulated soil moisture from the Noah land surface model. Publication is authorized by the Director, Bureau of Economic Geology.

\section{References}

Amosson, S., T. Marek, L. New, F. Bretz, and L. Stewart (2003), Estimated irrigation demand for the southern Ogallala GAM, in Groundwater Availability of the Southern Ogallala Aquifer in Texas and New Mexico: Numerical Simulations Through 2050, edited by N. T. Blandford et al., pp. B-2-B436, Tex. Water Dev. Board, Austin, Tex.

Bettadpur, S. (2007), Level-2 gravity field product user handbook, rev. 2.3, GRACE 327-734, CSR Publ. GR-03-01, 19 pp., Univ. of Tex. at Austin, Austin, Tex.

Cheng, M., and B. D. Tapley (2004), Variations in the Earth's oblateness during the past 28 years, J. Geophys. Res., 109, B09402, doi:10.1029/ 2004JB003028.

Cosgrove, B. A., et al. (2003), Real-time and retrospective forcing in the North American Land Data Assimilation System (NLDAS) project, J. Geophys. Res., 108(D22), 8842, doi:10.1029/2002JD003118.

Dennehy, K. (2000), High Plains regional ground-water study, U.S. Geol. Surv. Fact Sheet, FS-091i00, 6 pp.

Dingman, S. L. (2002), Physical Hydrology, Prentice Hall, Upper Saddle River, N. J.

Ek, M. B., K. E. Mitchell, Y. Lin, E. Rogers, P. Grunmann, V. Korev, G. Gayno, and J. D. Tarpley (2003), Implementation of Noah land surface model advances in the National Centers for Environmental Prediction operational mesoscale Eta model, J. Geophys. Res., 108(D22), 8851, doi:10.1029/2002JD003296.

Gutentag, E. D., F. J. Heimes, N. C. Krothe, R. R. Luckey, and J. B. Weeks (1984), Geohydrology of the High Plains aquifer in parts of Colorado, Kansas, Nebraska, New Mexico, Oklahoma, South Dakota, Texas, and Wyoming, U.S. Geol. Surv. Prof. Pap., 1400-B, 66 pp.

Homer, C., J. Dewitz, J. Fry, M. Coan, N. Hossain, C. Larson, N. Herold, A. McKerrow, J. N. Van Driel, and J. Wickham (2007), Completion of the 2001 National Land Cover Database for the conterminous United States, Photogramm. Eng. Remote Sens., 73(4), 337-341.

Hu, X. G., J. L. Chen, Y. H. Zhou, C. Huang, and X. H. Liao (2006), Seasonal water storage change of the Yangtze River basin detected by GRACE, Sci. China, Ser. D, 49(5), 483-491, doi:10.1007/s11430-0060483-5.

Maupin, M. A, and N. L. Barber (2005), Estimated withdrawals from principal aquifers in the United States, 2000, U.S. Geol. Surv. Circ., $1279,46 \mathrm{pp}$.

McGuire, V. L. (2007), Water-level changes in the High Plains aquifer, predevelopment to 2005 and 2003 to 2005, U.S. Geol. Surv. Sci. Invest. Rep., 2006-5324, 7 pp.

National Research Council Committee on Earth Gravity from Space, (1997), Satellite Gravity and the Geosphere: Contributions to the Study of the Solid Earth and Its Fluid Envelope, Natl. Acad., Washington, D. C.

Niu, G. Y., and Z. L. Yang (2006), Assessing a land surface model's improvements with GRACE estimates, Geophys. Res. Lett., 33, L07401, doi:10.1029/2005GL025555.

Paulson, A., S. Zhong, and J. Wahr (2007), Inference of mantle viscosity from GRACE and relative sea level data, Geophys. J. Int., 171(2), 497508.

Qi, S. L., A. Konduris, D. W. Litke, and J. Dupree (2002), Classification of irrigated land using satellite imagery, the High Plains Aquifer, nominal date, U.S. Geol. Surv. Water Resour. Invest. Rep. 02-4236.

Rodell, M., et al. (2004a), The Global Land Data Assimilation System, Bull. Am. Meteorol. Soc., 85(3), 381-394, doi:10.1175/BAMS-85-3381.
Rodell, M., J. S. Famiglietti, J. Chen, S. I. Seneviratne, P. Viterbo, S. Holl, and C. R. Wilson (2004b), Basin scale estimates of evapotranspiration using GRACE and other observations, Geophys. Res. Lett., 31, L20504, doi:10.1029/2004GL020873.

Rodell, M., J. Chen, H. Kato, J. S. Famiglietti, J. Nigro, and C. R. Wilson (2006), Estimating GW storage changes in the Mississippi River basin (USA) using GRACE, Hydrogeol. J., 15(1), 159-166, doi:10.1007/ s10040-006-0103-7.

Scanlon, B. R., I. Jolly, M. Sophocleous, and L. Zhang (2007), Global impacts of conversions from natural to agricultural ecosystems on water resources: Quantity versus quality, Water Resour. Res., 43, W03437, doi:10.1029/2006WR005486.

Schaap, M. G., F. J. Leij, and M. T. van Genuchten (2001), Rosetta: A computer program for estimating soil hydraulic parameters with hierarchical pedotransfer functions, J. Hydrol., 251(3-4), 163-176, doi:10.1016/S0022-1694(01)00466-8.

Shah, T., D. Molden, R. Sakthivadivel, and D. Seckler (2000), The global groundwater situation: Overview and opportunities and challenges, Int. Water Manage. Inst., Colombo, Sri Lanka.

Strassberg, G., B. R. Scanlon, and M. Rodell (2007), Comparison of seasonal terrestrial water storage variations from GRACE with groundwaterlevel measurements from the High Plains Aquifer (USA), Geophys. Res. Lett., 34, L14402, doi:10.1029/2007GL030139.

Swenson, S., and J. Wahr (2002), Methods for inferring regional surfacemass anomalies from Gravity recovery and Climate Experiment (GRACE) measurements of time-variable gravity, J. Geophys. Res., 107(B9), 2193, doi:10.1029/2001JB000576.

Swenson, S., D. Chambers, and J. Wahr (2008a), Estimating geocenter variations from a combination of GRACE and ocean model output, J. Geophys. Res., 113, B08410, doi:10.1029/2007JB005338.

Swenson, S., J. Famiglietti, J. Basara, and J. Wahr (2008b), Estimating profile soil moisture and groundwater variations using GRACE and Oklahoma Mesonet soil moisture data, Water Resour. Res., 44, W01413, doi:10.1029/2007WR006057.

Syed, T. H., J. S. Famiglietti, J. Chen, M. Rodell, S. I. Seneviratne, P. Viterbo, and C. R. Wilson (2005), Total basin discharge for the Amazon and Mississippi River basins from GRACE and a land-atmosphere water balance, Geophys. Res. Lett., 32, L24404, doi:10.1029/2005GL024851.

Tapley, B. D., S. Bettadpur, J. C. Ries, P. F. Thompson, and M. M. Watkins (2004), GRACE measurements of mass variability in the Earth system, Science, 305(5683), 503-505, doi:10.1126/science.1099192.

van Genuchten, M. T. (1980), A closed-form equation for predicting the hydraulic conductivity of unsaturated soils, Soil Sci. Soc. Am. J., 44, $892-898$.

Wahr, J., M. Molenaar, and F. Bryan (1998), Time-variability of the Earth's gravity field: Hydrological and oceanic effects and their possible detection using GRACE, J. Geophys. Res., 103, 30,205-30,229, doi:10.1029/ 98JB02844.

Wahr, J., S. Swenson, V. Zlotnicki, and I. Velicogna (2004), Time-variable gravity from GRACE: First results, Geophys. Res. Lett., 31, L11501, doi:10.1029/2004GL019779.

Wedin, D. A., W. H. Schacht, J. D. Volesky, J. T. Hiller, and N. Dobesh (2007), Was Weaver wrong? Soil moisture dynamics and rooting depths of sandhills grasslands, paper presented at the Ecological Society of America Meeting, San Jose, Calif., Aug.

World Health Organization (2003), The Right to Water, Health Human Rights Publ. Ser., vol. 3, New York.

Yeh, P. J.-F., S. C. Swenson, J. S. Famiglietti, and M. Rodell (2006), Remote sensing of GW storage changes in Illinois using the Gravity Recovery and Climate Experiment (GRACE), Water Resour. Res., 42, W12203, doi:10.1029/2006WR005374.

D. Chambers, Center for Space Research, University of Texas at Austin, 925 West Braker Lane, Suite 200, Austin, TX 78759, USA.

B. R. Scanlon and G. Strassberg, Bureau of Economic Geology, Jackson School of Geosciences, University of Texas at Austin, 10100 Burnet Road, Austin, TX 78758, USA. (gstras@gmail.com) 